\title{
The Economics of Marine Ecosystems: Reconciling Use and Conservation of Coastal and Marine Systems and the Underlying Natural Capital
}

\author{
Paulo A. L. D. Nunes • Andrea Ghermandi
}

Accepted: 24 September 2013 / Published online: 11 October 2013

C Springer Science+Business Media Dordrecht 2013

\section{Setting the Scene}

The recognition of the degree to which human activities can affect and depend on the health and preservation of marine and coastal ecosystems, and their goods and services, is today an indisputable fact (Halpern et al. 2012). However, as recently as a few decades ago, the marine environment could still be regarded as an acceptable final sink for land-based activities because of its high resilience and adaptive capacity and consequently be treated as a "universal sewer", in the words of Jacques-Yves Cousteau when addressing the US House Committee on Science and Astronautics on 28 January 1971. As of today, such out-of-sight and out-of-mind approach is patently no longer tenable. Human endeavors such as commercial fishing, offshore drilling, shipping, wind farms, recreational uses, and aquaculture have brought unprecedented change to marine and coastal ecosystems worldwide, either directly or indirectly-as in the case of anthropogenic emission of greenhouse gases and land runoff. Rising water temperature, ocean acidification, sea level rise, fisheries collapse, threats and severe degradation of entire marine habitats (such as coral reefs), and the increase in frequency and cumulative impacts of oil spills, harmful algal blooms and invasive species all

\section{P. A. L. D. Nunes}

Agriculture and Environment Services Department, Wealth Accounting and Valuation of Ecosystem Services (WAVES), The World Bank, Washington, DC, USA

P. A. L. D. Nunes

Institute of Marine Sciences, Spanish National Research Council, Passeig Marítim de la Barceloneta, 37-49, E-08003 Barcelona, Spain

P. A. L. D. Nunes

Department of Agricultural and Resource Economics, TESAF, University of Padova, Campus di Agripolis, Viale dell’Università, 16, 35020 Legnaro, PD, Italy

A. Ghermandi $(\varangle)$

Department of Natural Resources and Environmental Management, Faculty of Management, University of Haifa, 3498838 Haifa, Israel

e-mail: aghermand@univ.haifa.ac.il 
bear the fingerprint of human activities (Frieler et al. 2012; Halpern et al. 2008; IPCC 2007; Pauly et al. 2002). The central role of the protection and adequate management of the marine environment resources in promoting sustainable development has been recently strongly reaffirmed in The Future We Want, the final resolution adopted by the General Assembly at the United Nations Conference on Sustainable Development in Rio de Janeiro in June 2012 (UN 2012). Out of the 283 paragraphs of the document, twenty are dedicated to the 'Oceans and Seas', stressing "the importance of the conservation and sustainable use of the oceans and seas and of their resources for sustainable development, including through their contributions to poverty eradication, sustained economic growth, food security and creation of sustainable livelihoods and decent work, while at the same time protecting biodiversity and the marine environment and addressing the impacts of climate change " (page 30, paragraph 158). This same document identifies the world's oceans and seas as one key priority area and confers an unprecedented preeminence to the protection of marine biodiversity, reaffirming "the decision X/2 of the tenth meeting of the Conference of the Parties to the Convention on Biological Diversity, held in Nagoya, Japan, from 18 to 29 October 2010, that, by 2020, 10 per cent of coastal and marine areas, especially areas of particular importance for biodiversity and ecosystem services are to be conserved"(page 34, paragraph 177) by exploring the use of alternatives policy instruments, including marine protected areas (MPAs), and based upon the best available scientific information.

\section{Valuing the Benefits of Coastal and Marine Ecosystems}

The presence of a strong link between human welfare and the natural capital hosted by marine and coastal ecosystems is increasingly documented in the ecological and economic research and has come to serve as a robust argument in documenting the economic value of its benefits, or ecosystem services-for a review see Remoundou et al. (2009), Barbier et al. (2011) and Beaudoin and Pendleton (2012). More recently, the worldwide empirical analysis of coastal tourism demand and coastal recreation informs that natural assets, such as MPAs and biodiversity, play, at the margin, a significant role in explaining the market (and non-market) benefits derived from the tourism and recreational consumption activities - see Nunes and Onofri (2013) and Ghermandi and Nunes (2013), respectively. In addition, an estimated $61 \%$ of the world total GDP comes from the ocean and the coastal areas within $100 \mathrm{~km}$ of the coastline (UNEP 2006) and fisheries provide 4.2 billion people with more than $15 \%$ of the animal protein they consume (FAO 2010). As a result, coastal population densities are 2.6 times larger than in inland areas and benefit directly and indirectly from the provision of goods and services of coastal and marine ecosystems, which thus contribute to poverty eradication, sustained economic growth, food security and creation of sustainable livelihoods and inclusive work, while hosting large biodiversity richness and mitigating the impacts of climate change. ${ }^{1}$

The importance and urgency to mainstream the economic value of marine and coastal ecosystems and biodiversity seem to be today more than ever firmly established on the agenda of high-level policy and decision makers. A strong indication of such mindset can be found in the recent flourishing of high-profile initiatives that are either under development or in preparation internationally. Through its WAVES (Wealth Accounting and the Valuation of Ecosystem Services, http://www.wavespartnership.org), the World Bank is leading the efforts

1 By all commonly used measures and indicators, the human well-being of coastal inhabitants is on average much higher than that of inland communities (MA 2005). 
to develop ecosystem accounts to incorporate natural capital-including that of coastal and marine resources - into the accounts of its implementing partner nations. In addition, the TEEB4OC (TEEB for Oceans and Coasts initiative, the Economics of Ecosystems and Biodiversity, http://www.teebweb.org) will seek to extend the TEEB three-pronged approach of recognizing, demonstrating and capturing the value of biodiversity and ecosystem services to coastal and marine ecosystems around the world. The UK Natural Environment Research Council is leading a $£ 40.5 \mathrm{~m}$ research program on Ecosystem Services for Poverty Alleviation (http://www.nerc.ac.uk/research/programmes/espa), to assess the potential role of ecosystem services, including those provided by coasts, in achieving sustainable poverty reduction in four regions of the world. The Marine Ecosystem Services Partnership (http://mesp2.env. duke.edu) hosts and updates an extensive library of valuations of coastal and marine ecosystem services. A strong attention to the economic aspects of marine and coastal development and conservation is well present also in the work of the United Nations World Ocean Assessment (http://www.worldoceanassessment.org) and the European Commission's Maritime Spatial Planning and Blue Growth strategy (http://ec.europa.eu/maritimeaffairs/index _ en.htm).

\section{Architecture of the Special Issue}

In spite of the growing awareness, remarkably little is still known in quantitative terms about the economic flow of values from the marine environment, when compared to the terrestrial systems. To give a measure of this gap, only 34 of the 1,310 estimates of monetary values of ecosystem services that are included in the TEEB Ecosystem Services Valuation Database pertain to the marine environment and open oceans, ${ }^{2}$ as compared, for instance, to the 382 estimates for forests and woodlands (Groot et al. 2012). This knowledge deficit sets clear limitations to the effectiveness that governance and policies can achieve in the sustainable management of marine natural resources. Otherwise stated, there is a clear need "to measure better to manage better", as reiterated by Pavan Sukhdev's during TEEB's plenary session at the Convention of Biological Biodiversity (COP10) in Nagoya, Japan, 20 Oct 2010. In this context, this special issue (SI) embraces a science-to-policy approach, by exploring the use of the economic methodological toolbox to shed light on the magnitudes of the benefits provided by marine and coastal ecosystems, i.e. marine ecosystem services, and bring forward the discussion of the empirical econometric results to the relevant policy platforms.

The first paper in this SI (Swartz et al. 2012) explores the use of a global fish price database, covering 30,000 reported price items since 1950 to the present day, and develops a methodology for estimating missing prices for each fish group. This application of the methodology produces valuable knowledge-based economic information that is of particular interest to regions where reported prices are scarce or non-existent, including many developing countries. This information contributes to a further advancement of our ability to examine the economic contributions of marine fisheries to the global and national economies, which in turn constitutes the first, and fundamental, step for analyzing the effectiveness of various fisheries policy options and their contribution towards the achievement of a sustainable and healthy marine system.

2 The substantial larger number of observations (456) pertaining to coastal ecosystems, including wetlands and coral reefs, suggests that the lack of primary data may be less limiting for these ecosystems. 
This problem is addressed by Rolfe and Windle (2012) in their national level study of the Great Barrier Reef. ${ }^{3}$ This explores the use of the choice-modeling methodology, i.e. a survey based economic valuation instrument, to estimate the values of protecting the health of the Australian coral reef. The authors pay particular attention to how the economic values change in function of the characteristics of the beneficiaries, including variations in future usage (e.g. user vs. non-user groups), perceptions of the responsibility, and proximity from Brisbane, the state capital located at the southern limit of the Great Barrier Reef. Results confirm substantial welfare benefits that are estimated in $\$ 21.68$ per household per year for 5 years. Furthermore, for this nationally important iconic asset, distance decay reveals to be of limited importance, implying that the population base supporting its protection is likely to be larger than the one sampled. Finally, the study also reports high values for potential future visitation, suggesting that option values are also an important driver of responses, and therefore a value constituent of a successful policy targeted at the protection of the Great Barrier Reef.

The third paper considers another important aspect associated with the production of information-based knowledge for the onsite valuation of different sportfishing-benefit-sets by combining the use of the choice-modeling methodology with information about the level of the sampling effort (Kuriyama et al. 2013). The authors explore the use of a dataset that is composed by 37 fishing sites and 43,045 observations and is at the basis for proceeding with the estimation of consistent parameters estimates for the welfare changes associated to alternative asset management policies. Empirical model estimation results indicate that a recreational man-made shoreline sportfishing scenario that is characterized by an increase of $50 \%$ in the expected catch rates is associated to a welfare gain of $\$ 3.54$ per trip. The choice-based nature of the data collection reveals to be of particular importance for resource management purposes using onsite sampling information on actual choices made by a subset of the population where participation has a low incidence.

The fourth paper considers the use of benefit transfer methodology and the adaption of its procedures for cultural variations (Hynes et al. 2012). The authors explore the use of the nine different "cultural dimensions" developed by the GLOBE (Global Leadership and Organizational Behaviour Effectiveness) study so as to measure the differences and similarities between the societies studied, which are 73. With the use a subset of these metrics and a data-reduction technique, a cultural unit transfer variable is created and introduced into the valuation transfer function. In addition, a set of 95 studies focusing on the valuation of marine ecosystem services was used, including both peer-reviewed papers and grey literature. The coastal zone of Galway Bay in Ireland is the policy site used in the analysis. The benefit transfer exercise is performed according to both the individual ecosystem type and individual ecosystem service. According to the estimation results, the impact of using cultural dimensions in international benefit transfer is little, once differences in income levels have been accounted for. One reason for this may be associated to the fact that the majority of the study site estimates ( $85 \%$ ) refer to Ireland, England, Canada, USA, New Zealand and South Africa, a cluster of countries with ethnical and linguistic similarities. However, the authors argue that benefit transfer adjustments based on cultural factors could have higher impact in policy sites outside of this cluster, such as El Salvador, Columbia, or South Korea.

The fifth paper addresses the study of environmental damages created by oil spills (Loureiro and Loomis 2012). The authors use information on the recent Prestige oil spill to explore a policy scenario in which the oil spill affects marine Areas Beyond National

\footnotetext{
3 Note that, while this paper was originally commissioned for this special issue, it was published in advance of the other papers in this collection.
} 
Jurisdiction (ABNJ). In this context, one can identify damages that not are only confined to the country where the oil spill occurred, particularly in the case of passive use values and bearing in mind the public good nature of the underlying benefits. The authors make use of an online contingent valuation survey in three different European countries: Spain, United Kingdom and Austria. The valuation exercise focuses on the introduction of an oil spill prevention and response program in Spain. Economic valuation results show that passive use values estimates range between 124.37 Euro/household in Spain, to 80.87 Euro/household in the UK, and 89.08 Euro/household in Austria. These results inform the policy maker that the welfare losses caused by large oil spills are not confined to a single country and therefore invite for reflection on how to identify the affected population and design the compensation process, particularly in the light of the polluter-pays-principle adopted by the European Union.

The final paper addresses the issue of social discount rates in the context of inter-temporal economic analysis of investment programs in green infrastructure (Chiabai et al. 2012). These investments are characterized by long-term environmental impacts and it is fundamental for policy action to identify the appropriate social discount rate. The authors argue in favor of an ethically simple and intuitive approach regarding the choice of the social discount rate when designing and evaluating policy options with an impact on marine or terrestrial ecosystems. The rule is based on the idea that any policy maker should try to value equivalently and consistently a track of marine coastal area that is in its undeveloped (natural) state and another one that has been designated as appropriate for development (namely with the permission to build on it, e.g., for residential or industrial use). This in turn reflects the fact that the long term value of preserving undeveloped marine coastal areas is at least equivalent to the value of similar land (located in the same area) with permission to build up, and improvements to the former should be valuated using a discount rate that has been determined on the basis of such an "equivalency principle". The authors apply this rule to an empirical case study, the $€ 1.2$ billion public investment plan for the construction of a new seaport in the town of Pasaia, in the Basque Country, which is located in a coastal marine ecosystems with significant environmental value. The authors discuss the application of the "equivalency principle" to all natural sites located in the same administrative unit of reference, which have similar environmental attributes to the one assessed in the available valuation study.

\section{Economics of Marine Ecosystems: The Demand for Knowledge Policy-Information Products}

In this SI we have assembled a set of papers that combine a policy-oriented approach with empirical applications of economic valuation tools with the objective of producing information-based knowledge to advance the current understanding of the economics and management of coastal and marine ecosystems. We highlight, in particular, three areas that are critical for a better understanding of the links between the management and use of coastal and marine ecosystems and human welfare. First, we explore issues related to the spatial distribution of marine ecosystem services, including fisheries and non-market or passive use values (such as the sense of place and iconic assets). Such spatial dimension is particularly crucial for marine ecosystem services, since marine and coastal biomes often cross national boundaries or, as in the case of high seas, are beyond national jurisdictions, which constitutes a serious governance impediment to their sustainable management. Second, the economic valuation processes, and respective methodologies, produce monetary estimates that are generally not available in the format that is of interest to policy makers and may require scaling 
up of local estimates to the appropriate policy dimension. This includes providing for adequate discounting of future benefits, including those that derive from our moral responsibility towards future generations, and assessing the income/re-distributional effects involved in various policy scenarios (e.g., identifying the "winners" and "losers" of the policies)—for more details on the ethical issues involved see Dasgupta et al. (2013) and Jax et al. (2013). Third, marine passive values, which are not recognized in the economic accounts and may constitute a significant components of the total economic value of marine ecosystems, ${ }^{4}$ call for special attention in the development of survey-based instruments-as these represent the only tool that can be used to shed light in this category of benefits-including the study of the drivers that guide people's choices regarding the allocation of coastal and marine resources.

We argue that the present special issue makes a contribution to a further advancement of our ability to examine the economic contributions of marine ecosystems to human welfare. This constitutes the first and fundamental step for analyzing the effectiveness of various policy and management options and their contribution towards the achievement of a sustainable and healthy marine system. We also recommend that further research be undertaken into these issues, including demonstrating how knowledge-based products such as those produced by economic valuation tools may be used support better decision-making, and how they affect public policies and the practices of stakeholders in private organizations and civil society. In particular, special attention should be allocated to the integration of the results from natural sciences, economic assessment (both at the macro- and micro-economic levels), and management tools in the development of ecosystem-based solutions for oceans, estuaries and coastal areas to the current global challenges, including global climate change, ocean acidification, and the achievement of food security and poverty alleviation. Such efforts will consolidate the role of economic thinking and policy analysis of the effectiveness of various management options and their contribution towards the achievement of a sustainable, healthy marine system.

Acknowledgments The authors are thankful to Conservation International, under the Global Ocean Valuation research. Andrea Ghermandi is thankful to the European Commission, under contract agreement no. 265103 MedSeA-Mediterranean Sea Acidification in a Changing Climate, for its financial support. Paulo A.L.D. Nunes is thankful to the European Commission, under contract agreement no. 266445 Vectors-Vectors of Change in Oceans and Seas Marine Life, Impact on Economic Sectors, for its financial support.

\section{References}

(2010) FAO—Food and Agriculture Organization (2010) The State of World Fisheries and Acquaculture. Food and Agriculture Organization of the United Nations, Fisheries and Acquaculture Department, Rome

Barbier EB, Hacker SD, Kennedy C, Koch EW, Stier AC, Silliman BR (2011) The value of estuarine and coastal ecosystem services. Ecol Monogr 81(12):169-193

Beaudoin Y, Pendleton L (eds) (2012) Why value the oceans?. Discussion paper, The Economics of Ecosystems and Biodiversity (TEEB)

Chiabai A, Galarraga I, Markandya A, Pa'scual U (2012) The equivalency principle for discounting the value of natural assets: an application to an investment project in the Basque coast. Environ Resour Econ. doi:10. 1007/s10640-012-9589-8

Dasgupta P, Anant TCA, Basu K, Chopra K, Desai N, Gundimeda H, Kelkar V, Kolli R, Parikh K, Sen P, Shyamsundar P, Somanathan E, Sundaram K (2013) Green National Accounts in India: a Framework. Report by an expert group Convened? by the National Statistical Organization Ministry of Statistics and Programme Implementation Government of India, March 2013

4 A study by Eadie and Hoisington (2011) evaluates that the contribution of marine non-market value to range up $36.4 \%$ of the annual economic value provided by Australia's marine estate, which estimated to be $69.2 \$$ billion per year. 
de Groot RS, Brander L, van der Ploeg S, Bernard F, Braat L, Christie M, Costanza R, Crossman N, Ghermandi A, Hein L, Hussain S, Kumar P, McVittie A, Portela R, Rodriguez LC, ten Brink P (2012) Global estimates of the value of ecosystems and their services in monetary terms. Ecosyst Serv 1:50-61

Eadie L, Hoisington C (2011) Stocking up: securing our marine economy. Report Centre for Policy Development (CPD), Australia 70 pp

Frieler K, Meinshausen M, Golly A, Mengel M, Lebek K, Donner SD, Hoegh-Guldberg O (2012) Limiting global warming to $2^{\circ} \mathrm{C}$ is unlikely to save most coral reefs. Nat Clim Change 3:165-170

Ghermandi A, Nunes PALD (2013) A global map of coastal recreation values: Results from a spatially explicit meta-analysis. Ecol Econ 86:1-15

Halpern BS, Walbridge S, Selkoe KA, Kappel CV, Micheli F, D’Agrosa C, Bruno JF, Casey KS, Elbert C, Fox HE, Fujita R, Heinemann D, Lenihan HS, Madin EMP, Perry MT, Selig ER, Spalding M, Steneck R, Watson R (2008) A global map of human impact on marine ecosystems. Science 319(5865):948-952

Halpern BS, Longo C, Hardy D, McLeod KL, Samhouri JF, Katona SK, Kleisner K, Lester SE, O'Leary J, Ranelletti M, Rosenberg AA, Scarborough C, Selig ER, Best BD, Brumbaugh DR, Chapin FS, Crowder LB, Daly KL, Doney SC, Elfes C, Fogarty MJ, Gaines SD, Jacobsen KI, Karrer LB, Leslie HM, Neeley E, Pauly D, Polasky S, Ris B, Martin KS, Stone GS, Sumaila UR, Zeller D (2012) An index to assess the health and benefits of the global ocean. Nature 488:615-620

Hynes S, Norton D, Hanley N (2012) Adjusting for cultural differences in international benefit transfer. Environ Resour Econ. doi:10.1007/s10640-012-9572-4

IPCC-Intergovernmental Panel on Climate Change (2007) Climate change 2007: The physical science basis. Contribution of working group I to the fourth assessment report of the Intergovernmental Panel on Climate Change. Cambridge University Press, Cambridge, UK and New York, NY, USA, 996 pp

Jax K, Barton DN, Chan KMA, de Groot R, Doyle U, Eser U, Görg C, Gómez-Baggethun E, Griewald Y, Haber W, Haines-Young R, Heink U, Jahn T, Joosten H, Kerschbaumer L, Korn H, Luck GW, Matzdorf B, Muraca B, Neßhöver C, Norton B, Ott K, Potschin M, Rauschmayer F, von Haaren C, Wichmann S (2013) Ecosystem services and ethics. Ecol Econ. doi:10.1016/j.ecolecon.2013.06.008

Kuriyama K, Hilger J, Hanemann M (2013) A random parameter model with onsite sampling for recreation site choice: an application to southern California shoreline sportfishing. Environ Resour Econ. doi:10.1007/ s10640-013-9640-4

Loureiro M, Loomis JB (2012) International public preferences and provision of public goods: assessment of passive use values in large oil spills. Environ Resour Econ. doi:10.1007/s10640-012-9556-4

MA-Millennium Ecosystem Assessment (2005) Ecosystems and human well-being: synthesis report. Island Press, Washington, DC, p 155

Nunes PALD, Onofri L (2013) Beach 'lovers' and 'greens': a worldwide empirical analysis of coastal tourism. Ecol Econ 88:49-56

Pauly D, Christensen V, Guénette S, Pitcher TJ, Sumaila UR, Walters CJ, Watson R, Zeller D (2002) Towards sustainability in world fisheries. Nature 418(6898):689-695

Remoundou R, Koundouri P, Kontogianni A, Nunes PALD, Skourtos M (2009) Valuation of natural marine ecosystems: an economic perspective. Environ Sci Policy 12(7):1040-1051

Rolfe J, Windle J (2012) Distance decay functions for iconic assets: assessing national values to protect the health of the Great Barrier Reef in Australia. Environ Resour Econ 53(3):347-365. doi:10.1007/ s10640-012-9565-3

Swartz W, Sumaila UR, Watson R (2012) Global ex-vessel fish price database revisited: a new approach for estimating 'missing' prices. Environ Resour Econ. doi:10.1007/s10640-012-9611-1

UNEP_-United Nations Environmental Program (2006) Marine and coastal ecosystems and human wellbeing: a synthesis report based on the findings of the Millennium Ecosystem Assessment. UNEP, Nairobi, Kenya

UN-United Nations (2012) The future we want resolution 66/228 adopted by the general assembly. Available online at http://sustainabledevelopment.un.org/futurewewant.html 